脳血管内治療の近未来一機器の開発改良一

\author{
坂井 信幸, 今村 博敏, 坂井 千秋, 足立 秀光, 谷 正一, 徳永 聡, 船津 克之, \\ 別府 幹也，鈴木 啓太，足立 拓優，奥田 智裕，松井 雄一，吉田 泰規，川端 修平， \\ 秋山 亮, 堀内 一史 \\ 神戸市立医療センター中央市民病院脳神経外科
}

\title{
Future Direction of Neuro-Endovascular Therapy : Innovation in Device Development and Improvement
}

\author{
Nobuyuki Sakai, M.D., Hirotoshi Imamura, M.D., Chiaki Sakai, M.D., Hidemitsu Adachi, M.D., \\ Shoichi Tani, M.D., So Tokunaga, M.D., Takayuki Funatsu, M.D., Mikiya Beppu, M.D., \\ Keita Suzuki, M.D., Hiromasa Adachi, M.D., Tomohiro Okuda, M.D., Yuichi Matsui, M.D., \\ Yasunori Yoshida, M.D., Shuhei Kawabata, M.D., Ryo Akiyama, M.D., and Kazufumi Horiuchi, M.D. \\ Department of Neurosurgery, Kobe City Medical Center General Hospital
}

The continued development and improvement of devices is the most important factor to advance neuro-endovascular therapy. The endovascular treatment of intracranial aneurysms started with detachable coil technology and has been further developed with adjunctive device technology, including the hyper compliant balloon and the neck bridge stent. These technologies are all focused on tightly packing aneurysm with coils. The flow diverter operates on a totally different theory, whereby blood flow into the aneurysm is regulated with a fine mesh stent to achieve occlusion and shrinkage of the aneurysm. The Pipeline Flex was approved in 2015 and we have just started to evaluate this new technology in Japan. However, there will still remain some aneurysms that cannot be cured by the flow diverter. To treat these, we will have a new range of innovative devices, the PulseRider, WEB, Medina and others in the near future. In the field of carotid disease, carotid artery stenting has already overtaken endarterectomy in Japan with its acceptable results and patient desire for a less invasive modality. But, periprocedural ischemic stroke is still more frequent in CAS. A new generation of micro-mesh stents will hopefully resolve this problem beginning with the CASPER approved study just started in Japan. Average risk CEA patients can now enroll in this study and. Going forward, many new innovative devices will continue to be deployed in the field of neuro-endovascular therapy. As always, we should safeguard both their appropriate use and patient safety in order to best contribute to the development of this field.

(Received November 18, 2016 ; accepted November 28, 2016)

Key words : innovation, device, development, flow diverter, micro mesh stent

Jpn J Neurosurg（Tokyo）26:21-28, 2017

\section{背景と目的}

脳血管内治療は，いうまでもなく新しい機器と技術の
開発と改良がその発展の原動力である。新しい医療機器 がなかなか承認されず，わが国への導入が遅れているこ とを示すデバイスラグ（device lag）という用語が過去の

連絡先：坂井信幸， $=$ 650-0047 神戸市中央区港島南町 2-1-1 神戸市立医療センター中央市民病院脳神経外科

Address reprint requests to: Nobuyuki Sakai, M.D., Department of Neurosurgery, Kobe City Medical Center General Hospital, 2-1-1 Minatojima-minamimachi, Chuo-ku, Kobe-shi, Hyogo 650-0047 Japan 
Table 1 Approved devices for neuroendovascular treatment in Japan

\begin{tabular}{l|l|c|c|c}
\hline \multicolumn{1}{c|}{ Device } & \multicolumn{1}{|c|}{ Target } & 2005-2009 & $2010-2014$ & 2015 \\
\hline IV rt-PA (Alteplase) & AIS & 2005.10 & & \\
Precise/Angioguard XP & CAS & 2007.9 & & \\
Carotid Wallstent/Filter Wire EX & CAS & & 2010.2 & \\
Carotid Guardwire & CAS & & 2010.7 & \\
Protégé/Spider FX & CAS & & 2011.2 & \\
MoMa & CAS & 2009.6 & 2012.4 & \\
Onyx & AVM & & 2010.1 & \\
Enterprise VRD & AN & & 2012.9 & \\
Neuroform EZ & AN & & 2013.1 & \\
Wingspan & ICAD & 2010.4 & \\
Merci & AIS & & 2011.6 & \\
Penumbra & AIS & 2013.12 & \\
Solitaire & AIS & 2014.4 & \\
Trevo & AIS & & 2014.9 & \\
EmboSphere & Tumor, AVF & & & 2015.4 \\
LVIS & AN & & & 2015.4 \\
Pipeline Flex & AN & & & \\
REVIVE SE & AIS & & \\
\hline
\end{tabular}

AIS : acute ischemic stroke, CAS : carotid artery stenting, AN : aneurysm

ものとなるほど, 2010 年以降脳血管内治療領域ではわが 国に新しい機器が導入された（Table 1)。一方，新規デバ イスはその安全性や有効性が未知であり，十分に検証さ れていない段階で導入すればその成績を検証することが 求められる。本稿では, 脳動脈瘤と頝動脈狭窄症に焦点 を絞って，最近導入された機器に加えて今後導入される 機器について報告する。

\section{脳動脈瘤}

ガイディングシステムをはじめ多くの機器を使って血 管内から治療する脳動脈瘤であるが，離脱型コイルの開 発7)により本格的に始まった脳動脈瘤に対する血管内治 療は，バルーンやステントの開発と導入により大きく発 展してきた。2010年に導入されたコイル塞栓術支援用ス テントは，自己拡張型ステントの開発により始まった。

Neuroform (Stryker, Kalamazoo, MI, USA) は, 2002 年に米国における HDE 承認, 2005 年に欧州で CE マー クを取得し多くの経験が蓄積されている。その後, Enterprise VRD (Codman, Miami, FL, USA), LEO (Balt Extrusion, Montmorency, France), Solitaire AB (Covidien/Medtronic, Irvine, CA, USA), LVIS (MicroVention, Tustin, CA, USA), Liberty (Penumbra, Alameda, CA, USA) などが開発されている。わが国では 2010 年に脳動 脈治療用自己拡張型ステントとして Enterprise VRD が 承認されステント支援コイル塞栓術が始まり，2012 年に
は Neuroform EZ（Stryker）が，2015 年には LVIS が承認 された。これまではすべて瘤内にいかにコイルを充填す るかが目標であったが, 今, 最も注目されている機器 flow diverter（以下 FD）は，動脈瘤内にカテーテルを誘 導しコイルなどの塞栓物質を充填することなく母血管に 留置して，脳動脈瘤への血流を制御して動脈瘤の破裂や 増大を防ぎつつ，母血管を温存して脳動脈瘤を治療する 機器である. FD の代表は Pipeline（Covidien）で, Pipeline for Uncoilable or Failed Aneurysms (PUFS) 研究で は，大型または巨大 (ドーム径 $10 \mathrm{~mm}$ 以上), ワイドネッ ク (ネック部 $>4 \mathrm{~mm}$ ), ICA (petrous, cavernous あるい は paraophthalmic 領域）にある単一脳動脈瘤が対象とさ れて実施された。主要有効性評価項目は，治療手技 180 日後に標的脳動脈瘤に完全閉塞がみられ，親血管に狭窄 （>50\%）がなく代替治療も行われていなかつた被験者 の割合，主要安全性評価項目は，治療後 180 日目までに 同側脳卒中や神経学的死亡の割合であった。その結果, 108 例が登録され，脳動脈瘤の平均サイズは $18.2 \mathrm{~mm}$, ネック部の平均サイズは $8.8 \mathrm{~mm}, 85(78.7 \%)$ が大型

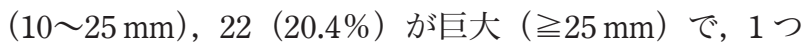
の脳動脈瘤に留置した Pipeline は平均 3.1 (中央値 3, 範 囲 1〜13）本，主要有効性評価項目では，集計対象の 104 例, 106 の標的脳動脈瘤中 78 動脈瘤に Pipeline のみで狭 窄を起こさず，完全閉塞が得られた（73.6\%，95\%事後 信頼区間 64.4 81.0\%)。安全性評価対象の 107 例中, 主 要同側脳卒中/神経学的死亡が 6 例にみられた（5.6\%, 
Table 2 Three flow diverter, approved or during study in Japan

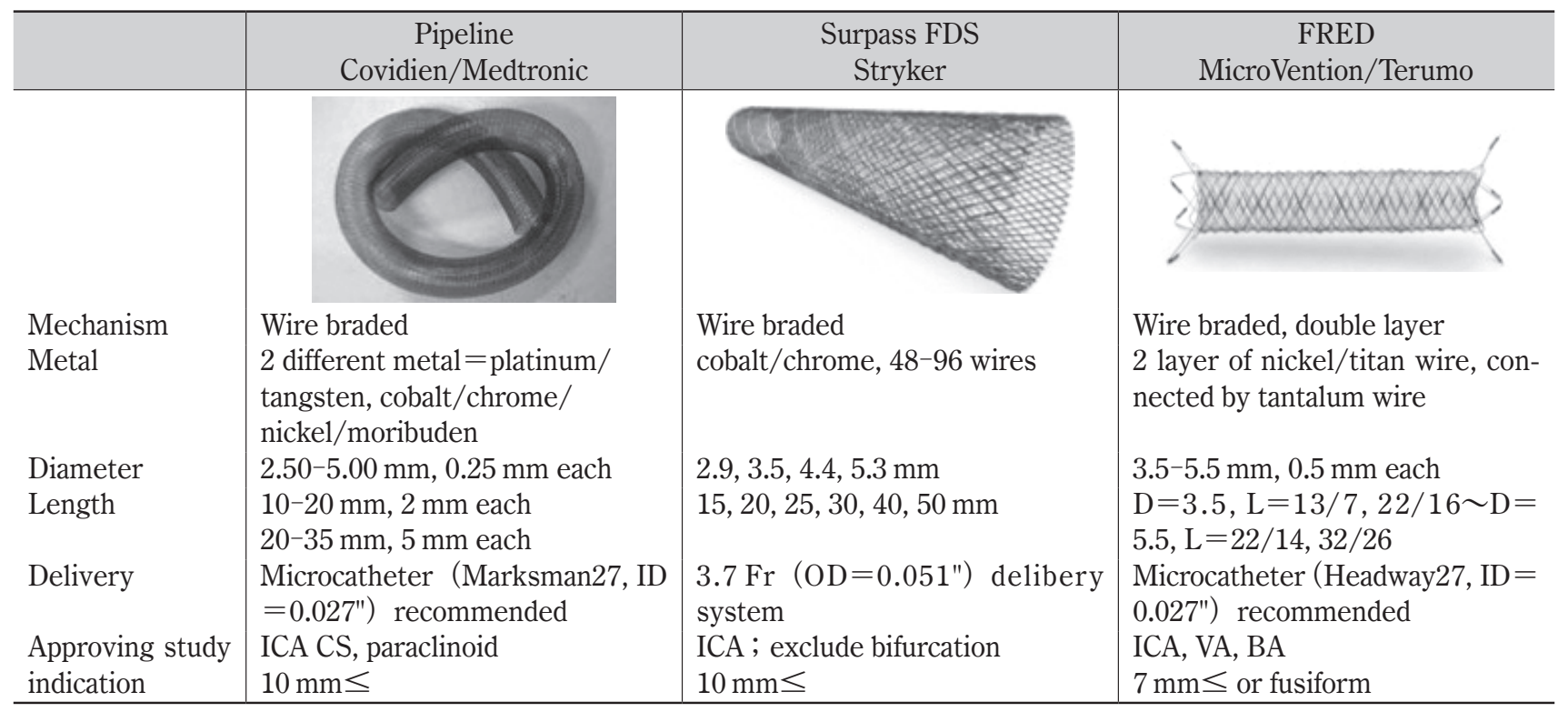

95\%事後信頼区間 $2.6 \sim 11.7 \%)^{3)}$ 。 その他にも Silk（Balt Extrusion), Surpass Flowdiverting Stent (Stryker), FRED (MicroVention) などが欧州で CE マークを取得し，すで に臨床応用されており, 多くの企業が開発に取り組んで いる (Table 2)。神経圧迫症状で発症した動脈瘤では, 瘤 内異物のない FD 治療は圧迫症状の改善効果が高い

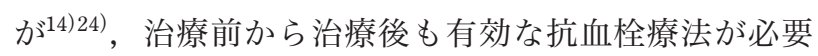
で11)23), 相当の習熟を要( ${ }^{5)}$, 出血 ${ }^{26) 28)}$ および血栓症 ${ }^{6) 12)}$ などの合併症も少なくなく, 自然歴や従来の治療法との 優劣は明らかになっていない機器である ${ }^{27)}$.

本邦では, 承認された Pipeline に加えて, Surpass と FREDの治験も行われた. Pipeline は delivery system を 改良した Pipeline Flexが 2015 年 4 月に承認された。 3 つ の FD の機器の概要を示す (Table 2). Pipeline を除いて 個別の機器の治験結果の詳細は承認申請前のため報告で きないが, 治験の概要は以下のとおりである。のべ 14 施 設で総計 79 例の被験者が FD 治療を受けた。治療後の脳 動脈瘤破裂 4 件 $(5.1 \%)$, 治療後の死亡 4 件 $(5.1 \%)$, 血 栓性閉塞 3 件 $(3.8 \%)$, 虚血性脳卒中 5 件 $(6.3 \%)$ であっ た。治療後の脳動脈瘤破裂は $\mathrm{FD}$ 治療の大きな課題とし てすでに多くの報告があるが, 大型のものではコイル併 用が有効と報告されている ${ }^{18)}$. また治療前から治療後比 較的長期にわたつて複数の抗血小板薬の投与が必要とさ れているが, clopidogrel の効果には個人差があるためそ の不応患者にはさまざまな対策が必要で, 術前に血小板 凝集機能を測定しその值によって効果に個人差が少ない prasugrel を導入して効果を上げたという報告があり ${ }^{10)}$,
国内の経験に基づくコンセンサスの形成が望まれる. Pipeline Flex の導入に際しては, 日本脳神経外科学会が 主導するデータベース登録が進められており，市販後の 調査（post market surveillance：PMS）にそのデー夕を活 用することになっている．周術期の安全性をこれとは別 に集計したところ治験時とは異なり, 治療後の破裂 1 件 $(0.5 \%)$, 死亡 1 件 $(0.5 \%)$, 血栓性閉塞 1 件 $(0.5 \%)$, 虚血性脳卒中 3 件 $(1.5 \%)$, 出血性脳卒中 2 件 $(1.0 \%)$, mass effect の悪化 4 件 $(2 \%)$ と良好であり, 機器の改良 と習熟によって有効な FD 効果を得ることができたこと に加え, コイル併用や適切な抗血栓マネジメントを心が けた結果ではないかと考えている（Table 3).

FD はこれまで治療困難であった大型, 不規則形状の 脳動脈瘤を治療可能とする画期的な機器であるが，椎骨 脳底動脈の血栓化動脈溜に対する効果は疑問視されてお $\eta^{25)}$ ，遠位動脈へのアクセスが困難な例ではそもそも技 術的に FD 治療を適用できない. また terminal type の大 型動脈留への効果も不確かであり, 従来のコイル塞栓術 でも再開通が多いことが知られているこのカテゴリーに 対して, 新しい機器の開発が進んでいる. 当科では従来 の開頭手術でも脳血管内治療でも治療が難しい症例に 限って, すでに欧州で市販されいくつかの報告 ${ }^{2122)}$ があ る PulseRider (Pulsar Vascular, Los Gatos, CA, USA) を倫理委員会の許可のもと導入した。代表例を示す.

62 歳, 男性の上方に向く最大径 $10.5 \mathrm{~mm}$ の前交通動脈 瘤を, PulseRider 2.7-3.5/10 T を支えに Orbit Galaxy 8 $\mathrm{mm} \times 24 \mathrm{~cm}$ を framing coil として合計 16 本のコイルで塞 
Table 3 Periprocedural events of flow diverter treatment in Japan

\begin{tabular}{l|l|l|l}
\hline & Approving study in Japan & $\begin{array}{c}\text { Pipeline Classic } \\
\text { in study }\end{array}$ & \multicolumn{1}{c}{$\begin{array}{c}\text { Pipeline Flex } \\
\text { post market }\end{array}$} \\
\hline Device & $\begin{array}{l}\text { Pipeline Classic } \\
\text { Surpass Streamline }\end{array}$ & Pipeline Classic & Pipeline Flex \\
& FRED & 22 & \\
$\mathrm{n}$ & 79 & $2(9.1 \%)$ & 200 \\
Rupture & $4(5.1 \%)$ & $3(13 / 6 \%)$ & $1(0.5 \%)$ \\
Death & $4(5.1 \%)$ & $2(9.1 \%)$ & $3(1.5 \%)$ \\
Stroke, ischemic & $5(6.3 \%)$ & 0 & $2(1.0 \%)$ \\
Stroke, ICH & $1(1.3 \%)$ & 0 & $1(0.5 \%)$ \\
Thrombotic occlusion & $3(3.8 \%)$ & $2(9.1 \%)$ & $4(2.0 \%)$ \\
Worsened mass effect & NA & & \\
\hline
\end{tabular}

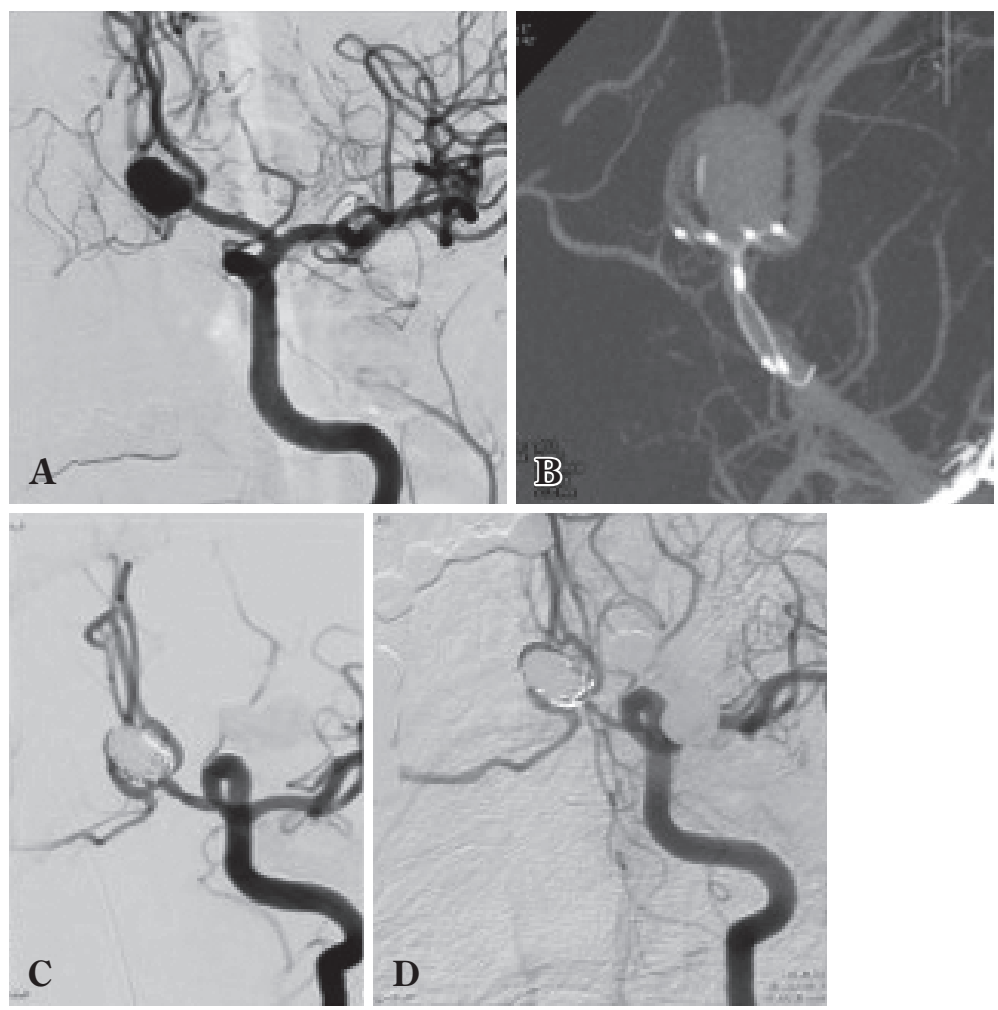

Fig. 1 A case of PulseRider assisted coil embolization

A : DSA AP view, before the treatment.

B : Xper CT, PulseRider open and cover the neck of Acom aneurysm.

C : DSA AP view, right after the treatment.

D : DSA AP view, 6 months follow up showed complete occlusion.

栓を行い，6 カ月後の血管造影で完全閉塞を確認した

(Fig. 1). 抗血栓マネジメントは多数経験しているコイ ル塞栓術支援用頭蓋内ステントと同じとしたが，金属量 は少なく多剂併用の期間，服用期間とも短縮できるとい う印象である。これまで前交通動脈の他に脳底動脈分岐 部，内頝動脈分岐部に計 8 例使用し，合併症および再開 通はなく 6 例に完全閉塞を得ている.
その他にも，母血管に機器を留置することなくこの再 開通が懸念されるネックの広い terminal type の脳動脈瘤 をターゲットに下 $2 つ の$ 機器が注目されている，1つは， WEB（Sequent Medical, Aliso Viejo, CA, USA）と呼ば れる機器で, 極細のワイヤーを編み込んだ楕円球系のデ バイスで，径は 4 11 mm，マイクロカテーテルを使っ て脳動脈瘤のネックをカバーするように脳動脈瘤内に留 


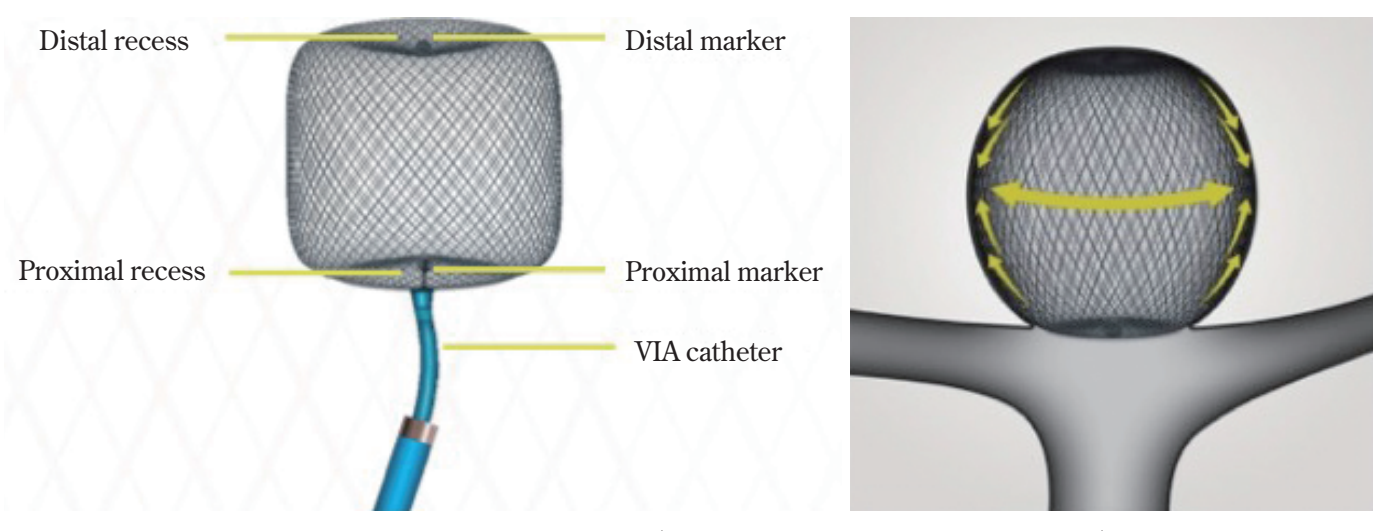

Fig. 2 Schema of WEB (Courtesy by Sequent Medical)

置する (Fig. 2).1つの機器で脳動脈瘤を充填し, ネッ クを中から有効にカバーする機構であり, 適切なサイズ の選択，そして適確な留置技術を要する。すずに欧州で は数千例の使用経験が蓄積されており WENCAST およ び French Observatory studyで, 合わせて 113 例の前向き 登録が行われ，技術的成功 $96.5 \%, 1$ 年後の閉塞が $82 \%$, 安定が $98 \%$, 治療および機器に関連する死亡 0 件, mRS 2 以上の悪化は 30 日以内で $2.7 \%$, その後 1 年までに $1 \%$ と, その安全性と有効性が示された ${ }^{16) 17)}$. 米国では治験 が行われ被験者の登録は終了した。本機器は機器の細径 化などの改良に合わせて本邦への導入が検討されてい る.もう1つの機器は MEDINA (Medtronic) である, ナイチノールでできた葉状の petalを連ねたデバイスで, 球形になる形状記憶を有し, 径は 4 9 mm である（Fig. 3).WEB とは異なり複数のデバイスを使用することが 想定されているが1), ネック部をカバーする網状の petal が瘤内に流入する血流を制御することにより治療効果を 得ることが期待されている，日米の治験が今後計画され る予定である。

\section{頚動脈狭窄症}

2006 年の第 1 次「医療ニーズの高い医療機器」に評価 AA（疾病の重篤性が高く, 当該医療機器等の医療上の有 用性が高い) とされた頝動脈ステントは, 2007 年 9 月に Precise と Angioguard XP (当時 Johnson \& Johnson/Cordis, Miami, FL, USA) が承認され, わが国でも正式に 頝動脈ステント留置術（carotid artery stenting：CAS）が 開始された。その根拠となった SAPPHIRE（Stent and Angioplasty with Patients at High Risk for Endarterectomy) 研究 29) に基づき, CAS は䅡動脈内膜剝離術 (carotid endarterectomy：CEA）の高危険群に適用するとされ, 脳

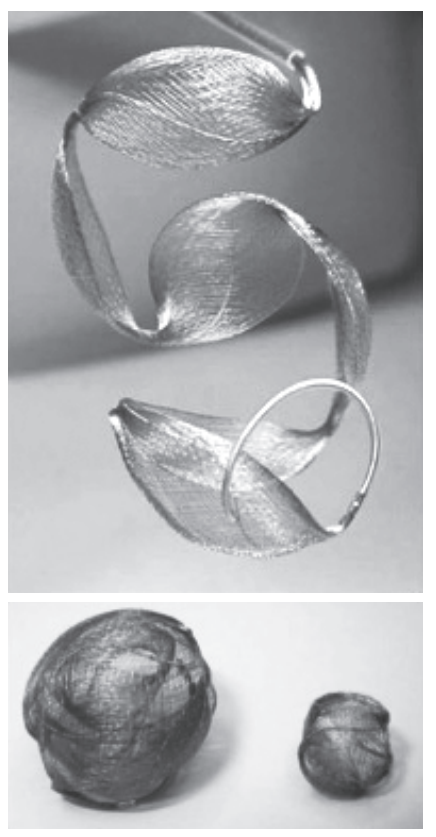

Fig. 3 Picture of MEDINA (Courtesy by Medtronic)

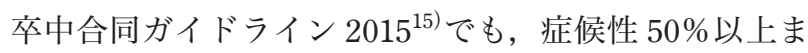
たは無症候性 80\%以上の狭窄を有し, CEA の危険因子 を伴うことがCAS の条件とされている。2010年に発表 された CREST (Carotid Revascularization Endarterectomy vs Stenting Trial)研究では CEA の normal/average risk 群 を対象にCAS と CEA の比較を行い, 両者が同等の周術 期合併症率および同側脳卒中の発生率であることを示し ている ${ }^{4)}$.これに伴い米国のガイドラインでは, CAS は CEA に代わり得る頝動脈狭窄症に対する血行再建術で あり, CAS の危険が通常程度の患者に対する CAS は, 術 者が十分にトレーニングを積み, 症候性 $6 \%$ ・無症候性 $3 \%$ を超えなければ考慮すべき治療法であると位置づけ ている ${ }^{9)}$. CREST では CAS に周術期の脳卒中が多く, 
Table 4 Micro- $^{-}$mesh carotid stent

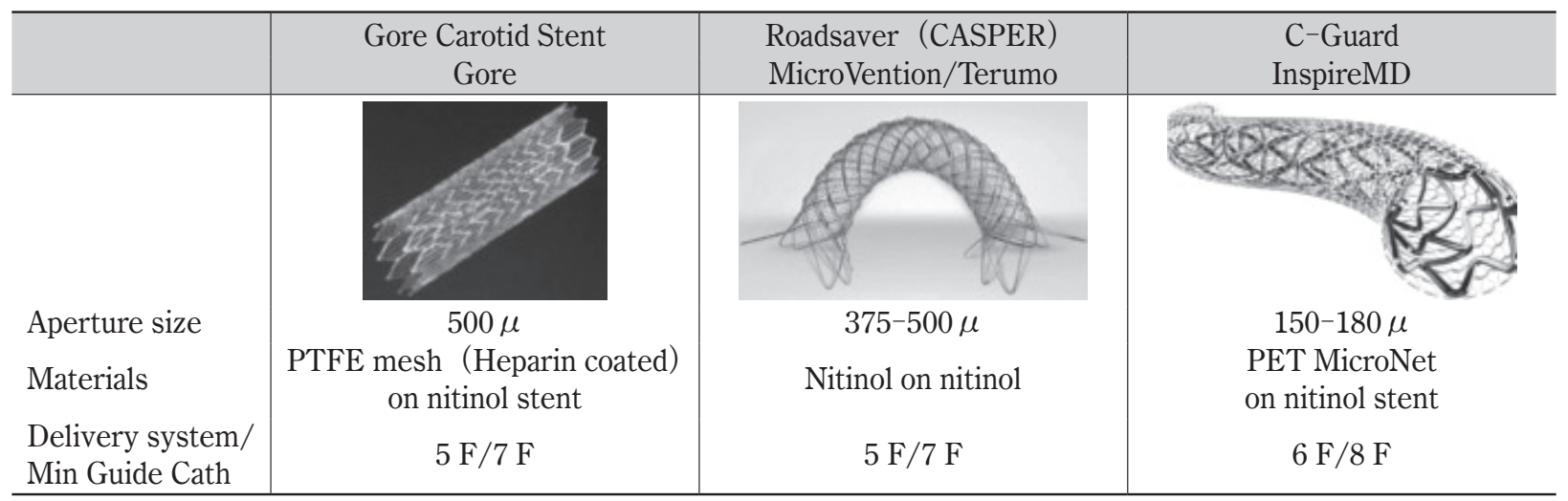
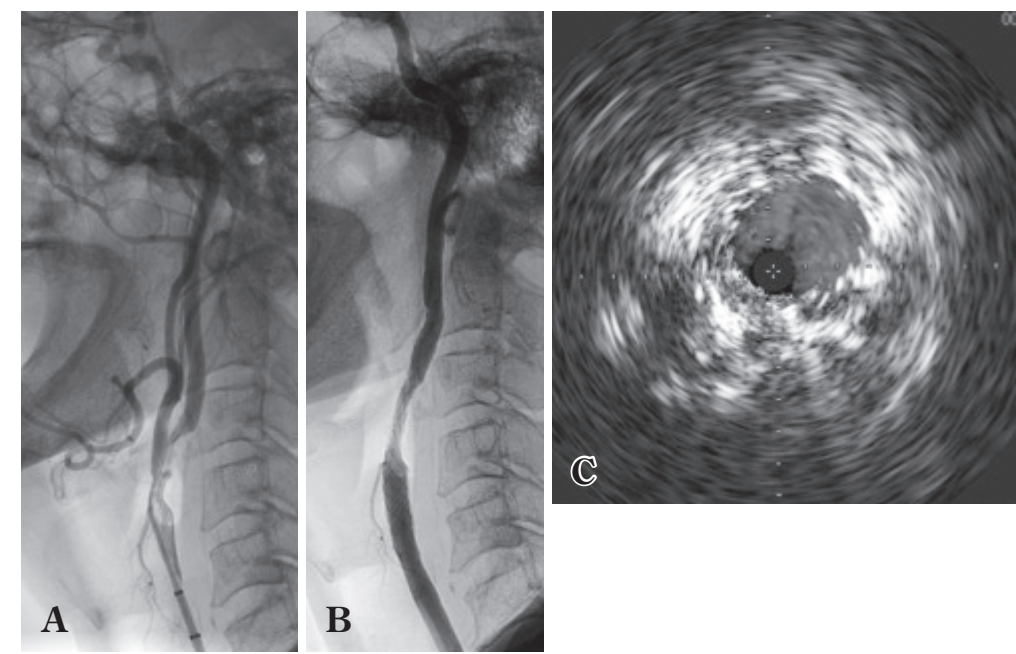

Fig. 4 A case of carotid artery stenting using CASPER

A : DA lateral view, before treatment.

B : DA lateral view, after stenting.

C : IVUS, after stenting showed no in-stent protrusion.

CEA に心筋梗塞が多かった。これは多くの比較研究でも 同じような傾向が確認されているため, CASおよびCEA 後の心筋梗塞が欧米より少ないわが国では留意すべき点 である。現在わが国では，2つのステント：Carotid WALLSTENT (Boston Scientific, Marlborough, MA, USA), Protégé (Medtronic) と 3 つの遠位型塞栓防止機 器: FilterWire EZ (Boston Scientific), Carotid GuardWire (Medtronic), Spider (Medtronic), そして近位で遠位塞 栓を防ぐ MoMa Ultra (Medtronic) が承認され, Cello（富 士システムズ), Optimo (東海メディカルプロダクツ) な どのバルーン付きガイディングカテーテルを加え本格的 な複数デバイス時代を迎えた。繰り返し行われている多 くの登録研究や調査で, proximal protection 法やプラー ク診断の活用などの工夫により，安全にCAS を行うため
の環境が整ってきたことが示されている ${ }^{13)}$.

CAS 後の虚血性脳卒中が多いことの原因の 1 つに, plaque が stentにより有効にカバーされていない可能性 が示唆されてきた ${ }^{2)}$. その欠点を克服する機器として, メッシュ状の層と拡張力を発揮する層を併せ持つ新世代 の micro-mesh stent が相次いで開発された（Table 4). C-Guard はメッシュ層にPETが使われており ${ }^{20)}$, GORE Carotid Stent では Goretex が使われている ${ }^{19)}$ 。そして欧 州では Roadsaver，日米では CASPER と呼ばれている MicroVention の double layer stent はナイチノールのメッ シュと拡張力を有するナイチノールワイヤーが組み合わ されている。不安定プラークでも留置後の in-stent protrusion がほとんどみられない(Fig. 4)。CASPER は 2016 年から国内治験が開始されており，その適格基準に CEA 
の average risk も含まれている. 結果次第では CAS の適 応が拡大される可能性があるため大きな関心が寄せられ ている。

\section{結 語}

脳動脈瘤と頝動脈狭窄症を中心に機器の開発と導入に 関する最新情報を報告した。機器の開発と改良によって 劇的に変化してきた脳血管内治療であるが，その発展の ためには適切な使用法の開発, 術者教育をはじめとする 治療環境の整備，そして結果検証が重要であることはい うまでもない。常に改良が加えられる医療機器では，適 応を守り, 安全に使用することを心がけ, 結果を正直に 公表しながら治療成績の向上に努めることが必要であ る. 企業が行う市販後調査への協力，学会が主導する登 録研究などにも積極的に貢献しなければならない。

著者全員は日本脳神経外科学会への COI 自己申告の登録を 完了しており, 筆頭著者が過去 3 年間に本論文に関して開示 すべき COI は下記のとおりです。

テルモ社より寄付金 (年間合計 200 万円以上)，日本ストラ イカー社, ジョンソンエンドジョンソンより講演料（年間合 計 100 万円以上）を受領しています.

\section{文 献}

1) Aguilar Perez M, Bhogal P, Martinez Moreno R, Bäzner H, Ganslandt O, Henkes H: The Medina Embolic Device: early clinical experience from a single center. J Neurointerv Surg 2016.[Epub ahead of print]

2) Aikawa H, Kodama T, Nii K, Tsutsumi M, Onizuka M, Iko M, Matsubara S, Etou H, Sakamoto K, Kazekawa K : Intraprocedural plaque protrusion resulting in cerebral embolism during carotid angioplasty with stenting. Radiat Med $\mathbf{2 6}$ : 318-323, 2008.

3) Becske T, Kallmes DF, Saatci I, McDougall CG, Szikora I, Lanzino G, Moran CJ, Woo HH, Lopes DK, Berez AL, Cher DJ, Siddiqui AH, Levy EI, Albuquerque FC, Fiorella DJ, Berentei Z, Marosfoi M, Cekirge SH, Nelson PK : Pipeline for uncoilable or failed aneurysms : results from a multicenter clinical trial. Radiology 267: 858-868, 2013.

4) Brott TG, Hobson RW 2nd, Howard G, Roubin GS, Clark WM, Brooks W, Mackey A, Hill MD, Leimgruber PP, Sheffet AJ, Howard VJ, Moore WS, Voeks JH, Hopkins LN, Cutlip DE, Cohen DJ, Popma JJ, Ferguson RD, Cohen SN, Blackshear JL, Silver FL, Mohr JP, Lal BK, Meschia JF ; CREST Investigators : Stenting versus endarterectomy for treatment of carotid-artery stenosis. NEng J Med $363: 11-23$, 2010.

5) Colby GP, Gomez JF, Lin LM, Paul AR, Coon AL : In situ removal of the pipeline embolization device: the 'corking' and 'pseudo-corking' techniques.J NeuroInterv Surg 5: e6, 2012.

6) Fiorella D, Hsu D, Woo HH, Tarr RW, Nelson PK : Very late thrombosis of a pipeline embolization device construct: case report. Neurosurgery 67 (3 Suppl Operative) : E313$314,2010$.

7) Guglielmi G, Vinuela F, Dion J, Duckwiler G : Electrothrombosis of saccular aneurysms via endovascular approach, Part 2: Preliminary clinical experience. J Neurosurg $75: 8-14$, 1991.

8) Hopf-Jensen S, Marques L, Preiß M, Müller-Hülsbeck S : Initial clinical experience with the micromesh Roadsaver carotid artery stent for the treatment of patients with symptomatic carotid artery disease. J Endovasc Ther $22: 220^{-}$ 225, 2015.

9) Kernan WN, Ovbiagele B, Black HR, Bravata DM, Chimowitz MI, Ezekowitz MD, Fang MC, Fisher M, Furie KL, Heck DV, Johnston SC, Kasner SE, Kittner SJ, Mitchell PH, Rich MW, Richardson D, Schwamm LH, Wilson JA ; American Heart Association Stroke Council, Council on Cardiovascular and Stroke Nursing, Council on Clinical Cardiology, and Council on Peripheral Vascular Disease: Guidelines for the Prevention of Stroke in Patients With Stroke and Transient Ischemic Attack. Stroke $45:$ 2160-2236, 2014.

10) Levitt MR, Ghodke BV, Hallam DK, Sekhar LN, Kim LJ : Incidence of microemboli and correlation with platelet inhibition in aneurysmal flow diversion. AJNR Am J Neuroradiol 34: 2321-2325, 2013.

11) Lylyk P, Miranda C, Ceratto R, Ferrario A, Scrivano E, Luna HR, Berez AL, Tran Q, Nelson PK, Fiorella D : Curative endovascular reconstruction of cerebral aneurysms with the pipeline embolization device : the Buenos Aires experience. Neurosurgery 64: 632-642, 2009.

12) McAuliffe W, Wycoco V, Rice H, Phatouros $C$, Singh TJ, Wenderoth $\mathrm{J}$ : Immediate and midterm results following treatment of unruptured intracranial aneurysms with the pipeline embolization device. AJNR Am J Neuroradiol 33 : 164170, 2012.

13) Miyachi S, Taki W, Sakai N, Nakahara I ; Japanese CAS Survey Investigators : Historical perspective of carotid artery stenting in Japan : analysis of 8,092 cases in The Japanese CAS survey. Acta Neurochir (Wien) 154:2127-2137, 2012.

14) Moon K, Albuquerque FC, Ducruet AF, Crowley RW, McDougall CG : Resolution of cranial neuropathies following treatment of intracranial aneurysms with the Pipeline Embolization Device. J Neurosurg 121: 1085-1092, 2014.

15）日本脳卒中学会，脳卒中ガイドライン委員会編：脳卒中 治療ガイドライン 2015. 東京, 協和企画, 2015.

16) Pierot L, Costalat V, Moret J, Szikora I, Klisch J, Herbreteau D, Holtmannspötter M, Weber W, Januel AC, Liebig T, Sychra V, Strasilla C, Cognard C, Bonafé A, Molyneux A, Byrne JV, Spelle L : Safety and efficacy of aneurysm treatment with WEB : results of the WEBCAST study. J Neurosurg 124:1250-1256, 2016.

17) Pierot L, Spelle L, Molyneux A, Byrne J ; WEBCAST and French Observatory Investigators : Clinical and anatomical follow-up in patients with aneurysms treated with the WEB device : 1-year follow-up report in the cumulated population of 2 prospective, multicenter series (WEBCAST and French Observatory). Neurosurgery 78: 133-141, 2016.

18) Rouchaud A, Brinjikji W, Lanzino G, Cloft HJ, Kadirvel R, Kallmes DF : Delayed hemorrhagic complications after flow diversion for intracranial aneurysms : a literature overview. Neuroradiology 58: 171-177, 2016.

19) Schönholz C, Yamada R, Montgomery W, Brothers T, Guima- 
raes $\mathrm{M}$ : First-in-man implantation of a new hybrid carotid stent to prevent periprocedural neurological events during carotid artery stenting. J Endovasc Ther 21:601-604, 2014.

20) Setacci C, Speziale F, De Donato G, Sirignano P, Setacci F, Capoccia L, Galzerano G, Mansour W ; IRON-Guard Study Group: Physician-initiated prospective Italian Registry of carotid stenting with the $\mathrm{C}-$ Guard mesh-stent: the IRONGuard registry. Rationale and design. J Cardiovasc Surg (Torino) 56:787-791, 2015.

21) Sheth SA, Patel NS, Ismail AF, Freeman D, Duckwiler G, Tateshima S : Treatment of wide-necked basilar tip aneurysm not amenable to $\mathrm{Y}$-stenting using the PulseRider device. BMJ Case Rep doi : 10.1136/bcr-2015-011836, 2015.

22) Spiotta AM, Chaudry MI, Turk AS, Turner RD : Initial experience with the PulseRider for the treatment of bifurcation aneurysms : report of first three cases in the USA.J Neurointerv Surg 8: 186-189, 2016.

23) Szikora I, Berentei Z, Kulcsar Z, Marosfoi M, Vajda ZS, Lee W, Berez A, Nelson PK : Treatment of intra- cranial aneurysms by functional reconstruction of the parent artery : the Budapest experience with the pipeline embolization device. AJNR Am J Neuroradiol 31 : 1139-1147, 2010.

24) Szikora I, Marosfoi M, Salomvary B, Berentei Z, Gubucz I : Resolution of mass effect and compression symptoms following endoluminal flow diversion for the treatment of intracranial aneurysms. AJNR Am J Neuroradiol 34 : 935939, 2013.

25) Toth G, Bain M, Hussain MS, Moskowitz S, Masaryk T, Rasmussen P, Hui : Posterior circulation flow diversion: a single-center experience and literature review. J Neurointerv Surg 7: 574-583, 2015.

26) Turowski B, Macht S, Kulcsár Z, Hänggi D, Stummer W : Early fatal hemorrhage after endovascular cerebral aneurysm treatment with a flow diverter (SILK-Stent). Neuroradiology $\mathbf{5 3}: 37-41,2011$.

27) van Rooij WJ, Sluzewski M, van der Laak C : Flow diverters for unruptured internal carotid artery aneurysms : dangerous and not yet an alternative for conventional endovascular techniques. AJNR Am J Neuroradiol 34: 3-4, 2013.

28) Velat GJ, Fargen KM, Lawson MF, Hoh BL, Fiorella D, Mocco J : Delayed intraparenchymal hemorrhage following pipeline embolization device treatment for a giant recanalized ophthalmic aneurysm. J NeuroIntervent Surg $\quad$ 4: e24, 2012.

29) Yadav JS, Wholey MH, Kuntz RE, Fayad P, Katzen BT, Mishkel GJ, Bajwa TK, Whitlow P, Strickman NE, Jaff MR, Popma JJ, Snead DB, Cutlip DE, Firth BG, Ouriel K ; Stenting and Angioplasty with Protection in Patients at High Risk for Endarterectomy Investigators : Protected carotid-artery stenting versus endarterectomy in high-risk patients. $N$ Engl J Med 351 : 1493-1501, 2004.

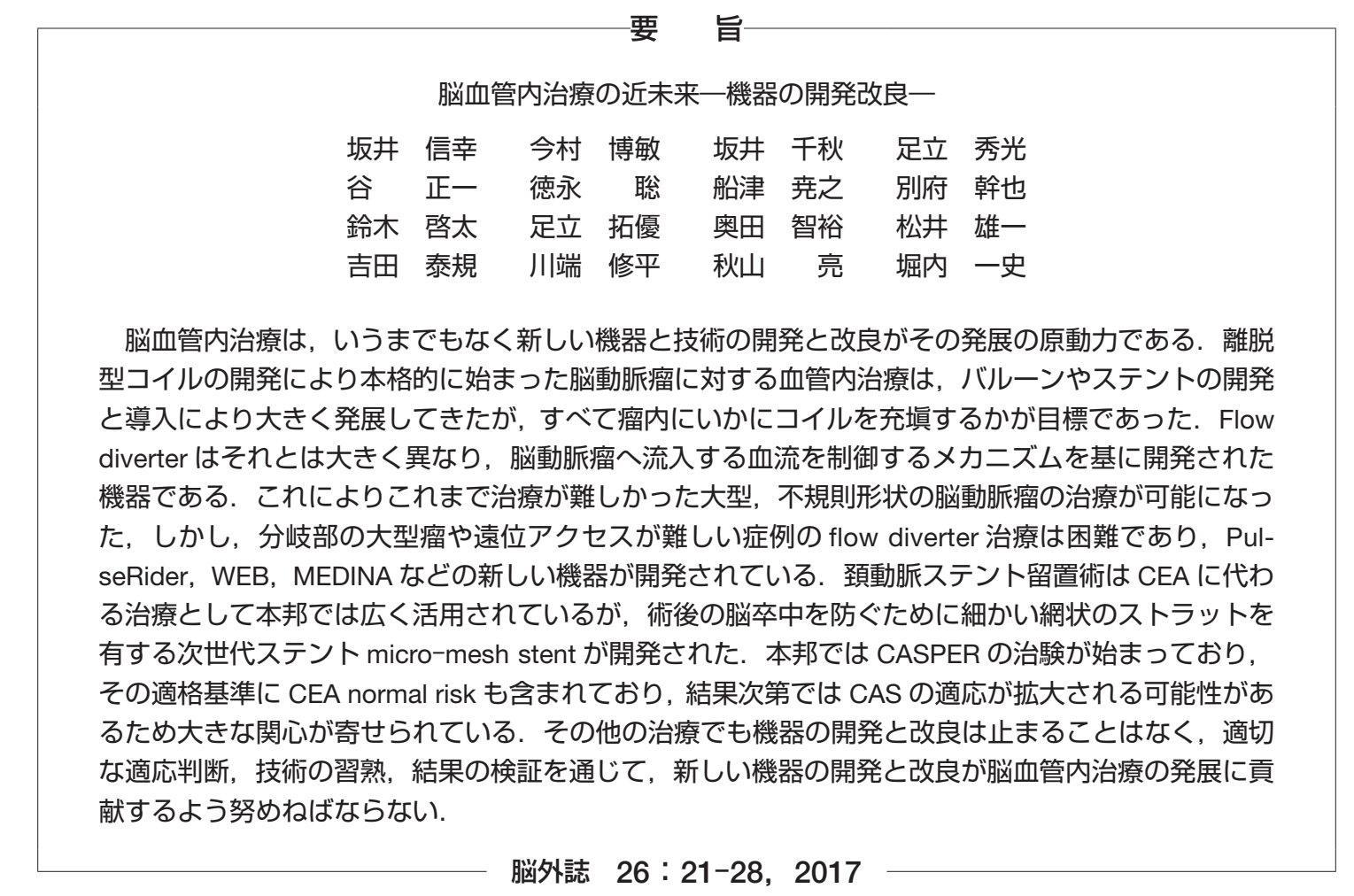

